The Polish Journal of the Arts and Culture. New Series 4

(2/2016): 47-78 [ARTICLE]

DOI: $10.4467 / 24506249$ PJ.16.010.6241

\title{
A heroine in the pangs of separation or a soul longing for the divine? Re-appropriated voices in the poetry of kathak dance repertoire
}

\author{
Katarzyna SkiBA
}

\begin{abstract}
The paper explores the ambivalent nature of poems that are part and parcel of the kathak dance repertoire in the context of a changing system of dance patronage during the 19th and 2oth centuries in North India. Through a textual analysis of selected thumri songs, the author investigates the use of śrngāra rasa (erotic sentiment) in this poetic genre in relation to its original, secular function and its interpretation in religious idioms. The comparison of traditional thumris with the compositions prevalent on the modern, classical dance stage shall underline a shift in the character of kathak performance (from romantic, sensual and intimate to devotional and impersonal). The attempts to locate thumri in the shastric framework and to 'purify' the content of these poems from the imprints of its lineage with tawa' if s culture is examined as part of the process of reinventing kathak in response to the tastes of a new class of patrons and performers and matching this art to the vision of Indian cultural heritage, propagated by nationalists.
\end{abstract}

Keywords: kathak, thumrī, Indian dance revival, nāyikā-bheda, dance

Katarzyna SкibA is a Ph.D student at the Jagiellonian University in Krakow. Her main area of research includes: South Asian performing arts, dance anthropology, sociology and postcolonial studies.

E-MAIL: katarzyna.skiba@yahoo.com 
Kathak is regarded as one of several classical Indian dance forms. It emerged in the north of the subcontinent, under the influences of both Hindu and Muslim culture. Nowadays, the Islamic substratum is largely veiled. The kathak repertoire is dominated by stories and motifs from Hinduism, and its aesthetic conventions are set in the frame of Sanskrit aesthetic theories. In particular, the dance explores the motif of rās-līla $\bar{a}^{1}$ - the amorous dalliance of lord Krishna with cowherdesses (gopīs) - as well as his childhood pranks. These scenes are portrayed in a rather realistic way, mirroring the every-day life of an Indian village. The heroine (often termed as a $n \bar{a} y i k \bar{a}$ ) is basically a folk woman, depicted in a relationship with her lover: waiting for him, thinking of him, meeting him, getting ready or going for a rendez-vous. The motif of $r \bar{a} s-l i \bar{l} \bar{a}$ appears in several parts of the kathak performance: from rhythmical tukrās, torās, and kavitts, through more expressive gats (gaits), to thumrīs - lyrical compositions, developing the emotional layer of the story. In thumrī, the body language is reinforced by rich, mimetic expression and vocal elaboration of the poem.

The erotic theme (śrngār) in kathak performance appears to be ambiguous and multidimensional. Most contemporary kathak artists emphasise its religious significance, considering the theme solely as a metaphor for the relationship between a devotee (a women, often Radha) and the god (Krishna). They often refer to the rich corpus of bhakti poetry that has developed this symbolism. Apart from thumri, kathak dancers also perform to the verses of famous bhakti poets, like Kabir, Surdas, Tulsidas, or Mirabai, which emphasise the devotional understanding of the rās-lìlā theme. Bhakti poetry has been included into the kathak repertoire around the middle of the twentieth century, whereas thumri constituted a part of it since the nineteenth century. The research on the evolution of the latter genre in the twentieth century indicates that there has been a tendency to exclude more sensual elements from thumri performance, and reintroduce the songs as a devotional art, matched to the context of modernity. ${ }^{2}$

${ }^{1}$ If no other language is indicated, the transcribed Indian terms in this paper are mostly Hindi words. Some of the words derive from Sanskrit, but are in common use among kathak dancers and dance scholars. The quoted lyrics are predominantly in the Braj Bhasha dialect of Hindi.

2 See: L. du Perron, Hindi Poetry in a Musical Genre: Thumri Lyrics, London 2007; P. Manuel, Thumri, Ghazal, and Modernity in Hindustani Music Culture [in:] Hindustani Music: Thirteenth to Twentieth Centuries, eds. J. Boer, F. Delvoye et. al., Delhi 2010, pp. 239-252; Idem, Thumri in Historical and Stylistic Perspectives, New Delhi 1988. 
The paper traces the parallel process in the context of kathak performance, focusing on thumri songs, which accompanied the dance. I consider this shift as a symptom of a broader process of the 'spiritualisation' of kathak that constituted the dance revival since the 1930s. In order to examine the process in terms of kathak repertoire, I shall refer to selected examples of thumrī songs used in kathak performance and compare their interpretations in the changing, historical context. I aim to highlight the ways in which the sociocultural and political circumstances have triggered and determined the transformation of kathak performance from a form of secular entertainment to classical, "high art", enriched with an aura of spirituality.

\section{A history of re-appropriation}

Kathak is recognised as one of the classical Indian dances, whereas thumri is classified as semi-classical, or the light classical genre of hindustāni music. A number of dance critics and kathak dancers claim that this dance is a product of an unbroken, centuries-old tradition. According to popular historiographies, each classical Indian dance is rooted in the dance tradition, described in Sanskrit treatises on performing arts - particularly the Nātyaśāstra. At the same time, it is believed that kathak originated from a tradition of storytelling, transmitted by male performers, called kathakas, of an alleged Brahmin origin. ${ }^{3}$ At the beginning, these wandering bards would spread the Hindu epic stories through melo-recitation, movements and gestures, in temples and courtyards, and later also in the courts of Hindu rajas, and Moghuls.

The shift to Muslim courts (dated approximately sixteenth century) is usually considered to be the main factor of kathak secularisation. In order to respond to the sensibilities and tastes of Muslim audiences, the artists would master the techniques of pure dance that nowadays characterise this dance form: a series of pirouettes, fast footwork, and rhythmical improvisation. The Mughal courts are regarded as the environment of the ongoing synthesis of Hindu and Persian dance traditions, devotional art of kathakas, and entertainment in the form of performing arts, provided by courtesans. Some dance historians also point at the spread of bhakti, Sufism, Vaishnava cults, and performances of the ras tradition, as important influences shaping kathak.

3 S. Kothari, Kathak: Indian Classical Dance Art, New Delhi 1989, p. 1. 
The "Golden Era" of kathak is attributed to the reign of nawab4 Wajid Ali Shah (1847-1856), during which Lucknow flourished as a centre of culture and arts patronage. There are several hereditary families of male dancers credited for transmitting kathak up to the present day in the system of three main kathak "schools": Lucknow, Jaipur and Banaras gharāna..$^{5}$ In the case of Lucknow gharāna $\bar{a}$, on which I focus here, this function is attributed to only one clan - descendants of artists employed at the nawab's court - brothers Kalka and Bindadin Maharaj. Both nawab Wajid Ali Shah and Bindadin Maharaj are also known as thumrī composers, who popularised and refined its form. Three sons of Kalka: Achchhan, Lachchhu and Shambhu Maharaj, started to teach kathak to non-hereditary dancers. The son of Achchhan Birju Maharaj is considered the greatest living master and the leading authority in determining the criteria for kathak authenticity.

The emphasis on the importance of hereditary clans of male teachers occurred along with a process of marginalising female dancers in kathak history: the courtesans called taw ' 'if s (Ur. tawa' 'if). Although they had contributed much to the development of dance and music in North India, nowadays many historians and artists deny that the tawa' if s ever danced kathak. Besides, there are almost no thumrī songs ascribed to female authors. The reason for the exclusion of courtesans as kathak artists lies in the broader context of sociocultural transformations, linked to the decolonisation and the accompanying cultural renaissance in India over the first half of the twentieth century.

From the end of the nineteenth century the status of dancers in South Asia had been gradually decreasing, partly due to the collapse of the former system of patronage, as well as the Anti-nautch campaign - the colonial propaganda - aimed at prohibiting institutions of temple danseuses (devadāsī), courtesans (tawä'ifs) and other dancing girls (generally termed by the British as "nautch"). Dance started to regain social respectability since the 1920s, thanks to the initiatives of Indian intellectuals, who relocated selected dance forms to new dance schools, and started to "purify" performing arts, to make

4 nawab (Ur. nawāb) - an honorific title granted to (usually Muslim) rulers who were provincial governors in the princely states in South Asia, subordinated to Mughal emperors. The kingdom of Oudh (Avadh) ruled by Wajid Ali Shah was annexed by British in 1856, and the nawab was exiled to Kolkata.

5 Some historians argue that Raigarh gharānā should be recognised as the fourth kathak school, as Raigarh was important centre of kathak patronage under the reign of raja Chakradhar Singh. 
them acceptable for modern audiences. As demonstrated by a number of scholars (Matthew H. Allen, Pallabi Chakravorty, Avanthi Meduri, Uttara Asha Coorlawala), the Indian classical dance revival, denotes not only a process of breathing new life into the art, but a broader metamorphosis of many aspects of the tradition, so that it could be examined as its reinvention ${ }^{6}$, or the invention of a new tradition. ${ }^{7}$ Among these aspects, the textual layer of the dance performance has undergone a significant shift. As is noticeable from the interviews with senior kathak artists, formerly the dance and vocals were complementary to each other in the process of communication. Therefore, we can assume that along with the dance, songs - as an integral part of the performance - have been also refashioned, in response to new, social functions, ascribed to the classical Indian performing arts.

The distorted visions of kathak history, discrediting tawa' if s as kathak dancers, emerged together with the process of kathak "classicisation", formally launched in the 1950 s in modern dance academies. The process denoted considerable changes in repertoire, technique, aesthetic conventions, social importance and system of training. The kathak revival was marked by few specific tendencies that can be termed as hinduisation, sanskritisation ${ }^{8}$, standardisation, institutionalisation, and democratisation. ${ }^{9}$ These tendencies were crucial for shaping the Indian national culture, and the concurrent construction of a national identity. ${ }^{10}$

The classical dance renaissance was a project of Western-educated, middle class elites, intending to re-appropriate the art according to puritan values, as a tradition representing "high culture", supposedly restored from the great past of India. New notions of female chastity, drawn from Victorian morality,

6 See: M. H. Allen, Rewriting the Script for South Indian Dance, "The Drama Review", Vol. 41, No. 3, p. $63-64$.

7 See: M. Walker, Kathak Dance: A Critical History, unpublished Ph.D. thesis, University of Toronto, Toronto 2004 .

8 The concept of sanskritisation, introduced in sociology by Srinivas (1956) and Raghavan (1956), was used in dance anthropology in the context of bharatanatyam 'revival' by Coorlawala (2004) to name the process of the incorporation of the Sanskrit aesthetics into the classical Indian dance. Similarly to bharatanatyam, kathak has been linked to old Sanskrit treatises, mostly Nätyaśāstra and Abhinaya darpaṇa through the implementation of certain conventions, aesthetic rules and nomenclature from these texts. Nowadays, the students of kathak institutes learn about Nätyaśāstra concepts in theory classes or from various manuals.

9 See: P. Chakravorty, Bells of change, Calcutta 2008.

${ }^{10}$ Ibidem. 
pushed the institution of taw $\bar{a}^{\prime}$ if s towards the margins of society. Dancers belonging to this community embodied an unrespectable model of femininity. On this account, they were discredited as kathak inheritors, and replaced by upper-caste women from "good", often Brahmin families. Performances were relocated to newly founded, public auditoria, and the training became formalised in dance schools, and academies, under the government patronage, in order to make education in kathak accessible to students from various, social groups.

The revivalists undertook an effort to standardise kathak, in order to adjust it to the vision of classical dance, propagated as an emblem of national heritage, founded on Sanskrit/Hindu legacy. These postulates corresponded to a romantic imagery of India, drawn from Orientalist discourse that crystallised a notion that the culture of India was ancient or refined, grounded in Hindu spirituality. Sanskrit aesthetic theory became a part of formal kathak education (leading to academic diplomas in dance), raising the status of the dance as a classical, sophisticated art. In succession, to bridge the existing gap between kathak technique and shastric conventions, Sanskrit nomenclature from old treatises has been introduced to name the postures, movements, gestures, mimetic expressions, and sentiments demonstrated in kathak. The subjects of the presentation started to be explained in terms of rasa theory ${ }^{11}$ and the classification of heroines $(n \bar{a} y i k \bar{a}-b h e d a)^{12}$, in reference to the Nātyaśāstra ${ }^{13}$.

${ }^{11}$ The theory of rasa (skt. "essence, "taste", "flavor") - the key-concept of aesthetic experience in old Indian art theory, formulated in the Nätyaśästra, and later commented by numerous Sanskrit theorists of arts. In the light of Nătyaśästra, rasa is an "aesthetic flavour" evoked through presentation of corresponding emotions (skt. bhava) by a performer, regarded as the ultimate goal of the art. Most of the Nātyaśāstra editions enumerate 8 rasas (erotic, comic, pathetic, furious, heroic, terrible, odious, marvellous), while Abhinavagupta (c. 1000) adds the taste of tranquility.

${ }^{12}$ năyika-bheda - a convention of presenting female characters in arts according to specified types. In the Nătyaśāstra heroines are classified into variety of types, on the basis of their age, social background, temperament, behaviour toward her lover, love experience, situation and emotions experienced in the amorous relationship. The convention is vividly explored in Sanskrit literature of kāvya type, Hindi poetry of rìti style, miniature paintings and performing arts.

${ }^{13}$ Nătyaśăstra - is an important Sanskrit treatise on the performing arts, attributed to the legendary sage Bharata, compiled between 2nd century $\mathrm{BC}$ and 3 rd century $\mathrm{AD}$. It describes many aspects of stage productions (theatre, music and dance), including structure of the play, division of theatrical space, types of dramas, heroes and heroines, types of acting, body movements, mimes and gestures, costumes and make up, theory of aesthetic experience, and 
To disconnect kathak from its previous, secular function in the courts and kothās (courtesans' salons), artists started to suppress its erotic tone and smother it with devotional connotations. A similar tendency to emphasise the spiritual and religious dimension in the revival of hindustāni music has been traced by Janki Bakhle, as populist rhetoric of bhakti nationalism, propagated by Paluskar, whose initiatives aimed at the "recovery" of the sanctity and purity of Indian classical music ${ }^{14}$. In dance, this objective was to be achieved by the modification of repertoire and the sacralisation of spaces for training and performance. ${ }^{15}$

\section{The purification of kathak performance}

The tendencies to purify and sanctify were instrumental in the modification of the textual layer of kathak. Some poetical-musical genres (like $\dot{g} a z a l s$ ) have been superseded by others (bhajans). In this process, thumri has partly lost its popularity in the kathak repertoire. Additionally, many poems have been rewritten in order to match the sensibilities of new patrons and audiences. Some of the lyrics have been changed, or reinterpreted in terms of devotionalism (bhakti). The manipulations in the content of thumri were facilitated by an ambiguity of the śrngāra theme. Many erotic songs, depicting love between a man and a woman, or addressed to a male patron, could have been framed within Krishna mythology. By reworking ancillary means of expression, they could also gain a spiritual dimension. Especially in dance performance, such a reinterpretation could have been achieved by erasing all the seductive movements, gestures, mimes, and glances that were made by courtesans in order to reinforce the sensuality of the performance and stir the imagination of potential clients. ${ }^{16}$ The new class of female performers were instructed not to move their hips, not to bite their lips and to avoid contact with the audience.

many more topics. It also presents mythological origin of theatre, connecting it to the Hindu religion.

${ }^{14}$ See: J. Bakhle, Two Men and Music. Nationalism in the Making of an Indian Classical Tradition, New York 2005.

${ }^{15}$ For instance, placing the statues of gods (particularly Krishna and Siva Nataraja), performing puja, or invocation to gods on stage, setting national dance festivals in old temple sites.

${ }^{16}$ See: M. Walker, Wounded with the Arrow of Her Eyelashes: Seduction and Sensuality in North Indian Dance [in:] Music, Dance and the Art of Seduction, eds. F. Kouwenhoven and J. Kippen, Delft 2013. 
The new generation of non-hereditary kathak dancers have also quit singing while dancing. Previously, songs were sung mainly by a dancer who used to enrich the lyrics with abhinaya (gestures and mimetic expressions) and voice modulation. In between the vocal sections, more dynamic elements of dance (especially footwork) were executed. Usually, the performance started from "seated abhinaya" - an artist would sing in a sitting position, demonstrating its poetic and symbolic nuances through glances and expressive gestures. Then, the tempo would pick up and the artist would start dancing. This style of enacting thumri while sitting is still continued by senior gurus of Lucknow gharāna of kathak, but it is increasingly rare on stage.

The disconnection of the singer-dancer leaves less scope for improvisation. Now, a dancer has to subordinate his/her own bodily expression to the rhythm, dictated by the musicians, and vice versa. Actually, it would be extremely tiring for a performer to execute both elements in the limited time allotted to a modern dance show. Before the process of kathak classicisation, during all night private gatherings ( $m a h f i l)$, an artist had plenty of time to perform and take breaks. In turn, due to the rich, slowly developing $a b h i-$ naya, the spectators were happy to watch one good soloist over several hours. Moreover, abhinaya - being a subtle, intimate form of communication - can be appreciated only at a close distance from the performer. Consequently, larger auditoria required a dancer to convey the narrative through bodily movements rather than mime, so the dancers deliberately started to give up or limit abhinaya.

Furthermore, the former system of patronage allowed an adept to devote significant time to training in singing, dancing, playing instruments, composing poetry, and mastering abhinaya. This could not be fully recreated in modern dance academies, where dance classes have limited length. Modern female dance students often treat dance training as an additional accomplishment, not a main profession. This approach was also shaped by the Anti-nautch movement. The image of a woman both dancing and singing was too related to the figure of a tawa' 'if. A professional danseuse (earning a living from dance) was at that time still considered to be synonymous with a prostitute, so respectable ladies preferred to remain "amateur dancers" earning from other professions, or being supported by their husbands. ${ }^{17}$ The

\footnotetext{
${ }^{17}$ Nowadays, the situation is changing, and many dancers want to be regarded as professional dancers. Nevertheless, the ability to both sing and dance is vanishing in kathak. Dancers have no time to become fully accomplished in music, or vocal, so a singer and a dancer
} 
practice of performing for free helps in refashioning kathak as not only a form of entertainment, but a kind of spiritual mission. On the other hand, the performers must have enough private or government funds to develop their career.

One of the kathak danseuses, who continues the old tradition of seated abhinaya, and singing to dance (including gazals) is Uma Sharma. She was, however, criticised for this practice by “kathak Queen” Sitara Devi, a daughter of the hereditary guru Sukhdev Maharaj. She complained that in this way, Sharma brings kathak "back to the brothel". ${ }^{18}$ Other dancers, like Damayanti Joshi, decided to perform abhinaya only while standing, since the seated $a b h i$ naya was particularly stigmatised. ${ }^{19}$ A similar "cleansing" of thumri from the "seated abhinaya" was noticed in the world of hindustāni music. In the 1970 s there were almost no female vocalists who would continue this practice in concert halls. ${ }^{20}$ Concerning the musical aspect of kathak performance, the disappearance of the accompanying sarangi - an instrument that has been also discarded for its association with tawa' if culture - has also been observed.

According to Sharma, Birju Maharaj and herself are the last artists who perform the "real kathak", with its essential qualities of abhinaya. ${ }^{21}$ Various dance historians also tried to re-evaluate the art of seated abhinaya, claiming that it has been evolved by Shambhu Maharaj. ${ }^{22}$ The presence of a dancing male on stage neutralised all associations with the $t a w \bar{a}$ 'if s. It was only the female body that could be read as sexual and sinful. This may explain why Sharma provoked controversy for singing gazals, or presenting "seated $a b$ hinaya", while the same elements, exposed by Birju Maharaj, with a face smeared with sandal paste, are highly appreciated by the audience (see picture 1).

Along with the shifting emphasis on bhakti mood, a gradual decrease in the popularity of $\dot{g} a z a l s$ has also been observed. Nowadays, gazals, expressing Muslim sensibilities, and "relegated" to film or pop-culture ${ }^{23}$, are almost out of fashion as an accompaniment for kathak (see picture 2). Mean-

remain separate artists.

${ }^{18}$ Arjun Mishra, pers., conv., Lucknow, April 11, 2015.

${ }^{19}$ Damayanti foshi: Manaka's daughter, Materials of Sparrow, 1998, p. 20.

${ }^{20}$ P. Manuel, pers. conv., New York, February 24, 2016.

${ }^{21}$ U. Sharma, pers. conv., New Delhi, March 27, 2014.

${ }^{22}$ S. Kothari, op. cit., p. 33.

${ }^{23}$ P. Manuel, Thumri, ghazal..., p. 249. 
while, thumrī - refashioned as a light-classical musical genre - is still taught to students and performed to dance, especially by exponents of Lucknow gharāna. The problem of their association with kotha culture could be resolved through a manipulation of the content, which was a manageable task due to the ambiguity of the Radha-Krishna theme, suggestive language, and possibility for various ways of interpretation in thumrì.

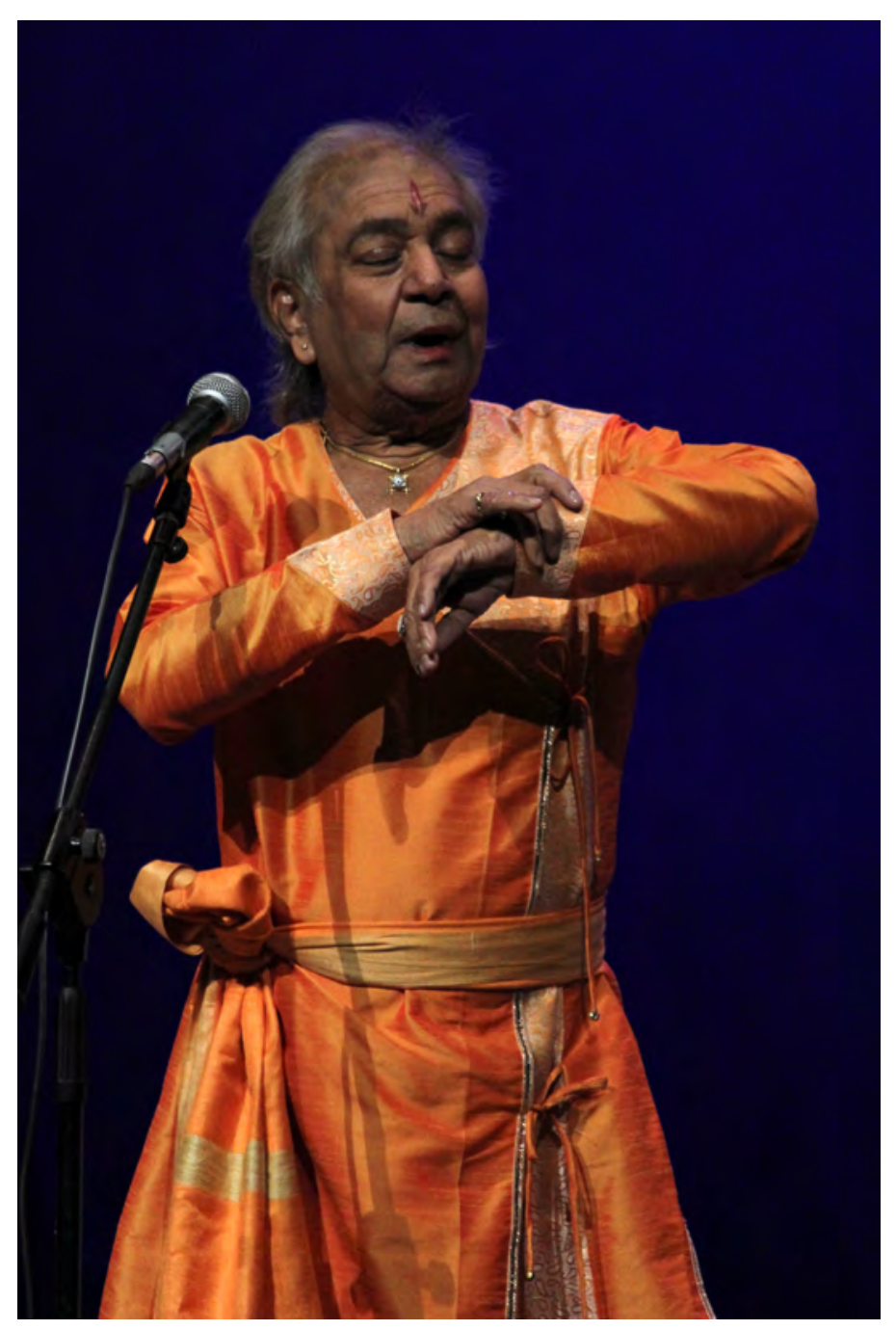

Figure 1: Birju Maharaj illustrating the motif of cher-chār, New Delhi 2015 (photo by author). 


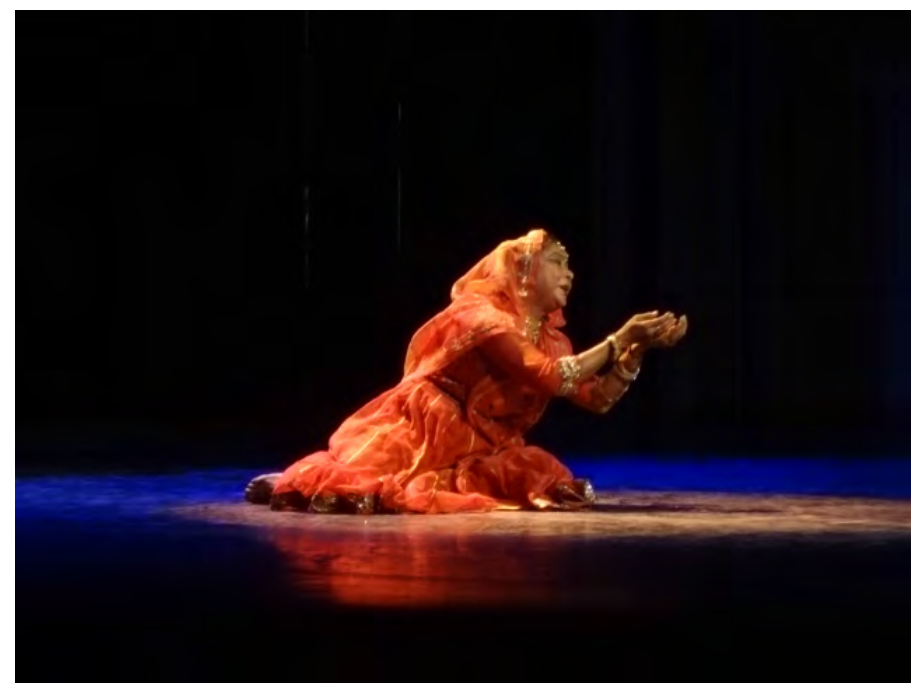

Figure 2: Saswati Sen performing to a gazal in the style of "seated abhinaya", New Delhi 2014 (photo by author).

\section{The ambiguity of śrngāra}

The love stories of Krishna and the gopis (Radha in particular) are popular motifs both in riti and bhakti poetry. The former is considered highly sensual and secular, while the latter - metaphorical and spiritual. This may explain why rìti poetry ${ }^{24}$, exploring human love (skt. laukika śrnigāra), found no place in the kathak repertoire, in spite of its strong association with court culture. Instead, in reference to bhakti poetry, the motif of the gopis' longing for Krishna prolonged thumri and kathak as an exposure of divine love (skt. alaukika śrngia $r a$ ). The poets of bhakti tend to identify themselves with the heroine, as a symbol of a devotee (bhakta), or an individual soul (jīvātmā), yearning for union with the Universal Soul (paramātmā), personified as Krishna. The same perspective has been taken by kathak performers. By enacting the bhakti songs, inducing religious feelings, the dancers could raise their social acceptance. ${ }^{25}$ To clarify the difference, dance critics, historians, and artists themselves tend to highlight the bhakti dimension in kathak. "It is worth noting that a major lot of the Kavya, used as complimentary to nrtya,

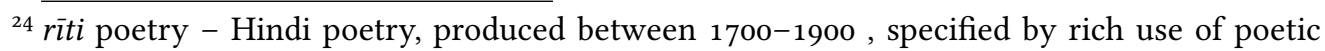
figures, borrowed from Sanskrit poetry theory and dominated by erotic themes (śrngāara).

${ }^{25}$ C. Jyotishi, Nayika Bheda in Kathak, Delhi 2009, p. 125. 
is Bhakti oriented, and not Riti oriented" - argues Chetna Jyotishi Beohar ${ }^{26}$, the former director of Kathak Kendra. She expounds:

Krishna is a wonderful blend of alaukika plus laukika lilas... a disciplined expression of human behavior is evident in plenty in Kṛ̣na’s character. If one visualizes the relationship between Gopīs and Kṛ̣ṇa in the light of Jīvātmā-Paramātmā philosophy, there remains absolutely no reason for doubt about the orderliness of behavior between the two. Because then, the emotions become boundless, and the so-called Laukika and societal controls become thin. ${ }^{27}$

The court culture in nineteenth century North India fostered the patronage and production of rìti poetry, in which śrngāra rasa had rather secular connotations. Nevertheless, the academic approach to the bhakti-riti division, shared by Snell is to locate both moods on a continuum, recognising that the devotional was never fully replaced by the mannerist, and that, in any case, the line of distinction may be difficult to trace. ${ }^{28}$ In my opinion, this situation is relevant to the tradition of thumri in kathak dance, especially if we consider the plethora of communities performing these songs, and various contexts of its presentation.

The motif of śrngāra in a dance performance could have already raised divergent associations in the court milieu, allowing various ways of decoding the message. Male kathaks, who are believed to perform more devotional pieces, could have used the songs as a vehicle to praise Krishna and Radha, whereas courtesans could have aimed to evoke erotic sentiments through the same stories, in order to attract clients. Taking into consideration their profession and religious affiliation (the majority of the tawä'if s were Muslims), we can assume that the courtesans must have shared a secular approach toward the Krishna stories, and they appreciate the artistic qualities of the theme. Peter Manuel identifies thumrī and gazal performance in the nineteenth century as primarily a courtesans' repertoire, designed to accompany kathak dance. ${ }^{29}$ The investigation of old thumri content, along with the social context of the performance, indicates that many of thumrīs were dance-

\footnotetext{
${ }^{26}$ Ibidem, p. 124 .

${ }^{27}$ Ibidem, p. 123.

${ }^{28}$ R. Snell, The Hindi Classical Tradition: A Braj Bhāṣā Reader, London 1991, p. 34.

${ }^{29}$ P. Manuel, Thumri, ghazal, ..., p. 243.
} 
songs of seductive character, mainly performed by dancing girls, during mahfils.

As pointed out by Lalita du Perron, although thumrī usually expresses the voice of women, there are few thumrī lyrics, ascribed to female composers. ${ }^{30}$ There are, however, some records of female authors of these songs. ${ }^{31}$ Apart from courtesans, there was a group of male artists, who composed thumri songs, using the agnomen 'Piya'. Nowadays, they are mostly credited for the authorship of thumri. Some songs are believed to be written by nawāb Wajid Ali Shah, under his pen-name 'Akhtar Piya'. We can suspect that, when the $t a w \bar{a}$ 'if s were marginalised, male dancers could have adopted their songs, and included them in their own repertoire, slightly reworking their content, and emphasising the bhakti element.

Both kathak and thumri are believed to have been developed in nineteenth century Lucknow, particularly due to the patronage of Wajid Ali Shah. ${ }^{32}$ The granduncle of Birju Maharaj - Bindadin Maharaj - apart from being a great dancer, is considered a prominent thumrī composer. The compositions ascribed to Bindadin are most frequently performed by present-day kathak dancers. It is commonly believed that he wrote around 1500 thumri songs ${ }^{33}$, although kathak dancers perform a limited number of compositions. According to Jyotishi, only 30-40 thumrīs of Bindadin are in vogue, and Birju Maharaj himself performs abhinaya on just a few selected compositions. ${ }^{34}$ Contemporarily, kathak dance is enacted with thumri mostly by Lucknow gharānā exponents. Birju Maharaj, and his son Jai Kishan Maharaj, continue to compose such songs.

\section{The aesthetics of thumri}

Generally, thumrī songs are short compositions, written in Braj Bhasha, designed for solo presentation and interpretation. They can be elaborated by dancers and singers. On the one hand, we can distinguish nrtya pradhāna

\footnotetext{
${ }^{30}$ L. du Perron, Hindi Poetry... .

${ }^{31}$ P. Chakravorty, pers. conv., Swarthmore, February 17, 2016.

${ }^{32}$ There are, however, many other theories about earlier origin of thumrī, linking the genre with both Sanskrit texts, and folk traditions.

${ }^{33}$ L. Garg, Kathak nrtya, Hathras 1969, p. 30. According to Khokar, Bindadin composed around 150 thumrīs.

${ }^{34}$ C. Jyotishi, op. cit., p. 128.
} 
thumrī, used in the performances of kathak dancers, and courtesans, who conveyed the poetic content through body movements, glances and mimetic expression. On the other hand, there are gāna pradhāna thumrī, rendered by vocalists, using interpretation and manipulation of voice. Both variants share common themes. ${ }^{35}$

According to another categorisation, the compositions can be classified as bandiś thumrī and bol banāv (or bol banao) thumrī. Both bandiś and bol banā $v$ thumrī primarily evoke śrngigàra rasa. Bandis ${ }^{36}$ focuses on playful, light subjects, like Krishna's pranks and teasing cowgirls. These motifs provide narrative more suitable for fast and rhythmic presentation through dance movements and gestures. Bandiś thumrī was developed by courtesans in the Lucknow court. Bindadin Maharaj also mainly composed this type of thumri. Bol banā $v^{37}$ thumrīs are slower, with shorter lyrics, devoid of coquetry, intended to be performed in a more poignant way. It emphasises melodic improvisation over suggestive gestures and text. As a vehicle for profound, emotional expression, it explores the motifs of loneliness and separation from a beloved (viraha). This style of thumrì has been developed in Benares, under stronger folk influences.

As pointed out by Peter Manuel and Lalita du Perron, the thematic scope of thumri themes in the eighteenth century was broader than the contemporary repertoire, including both religious and obscene material, reflecting the social life of courtesans. More frivolous compositions seemed to disappear from the modern repertoire, or they have been "re-appropriated" by replacing "vulgar" words with neutral ones. Bandis țumrī gradually lost its popularity, and was replaced by the more abstract and slower bol banā $v$ thumri. In the context of kathak, bandis thumrì is still performed, as the predominant form of Bindadin's legacy. Nevertheless, it is often introduced as devotional compositions in kathak performance. The motif of viraha is explained as a metaphor of an individual soul yearning for union with the divine (paramātma). ${ }^{38}$

In terms of textual layer, thumrīs are rather simple lyrics, mostly lacking in originality, using the same, conventional motifs and phrases. The ambiguity inherent in the words, or a theme of a song, provides a space for creative

${ }^{35}$ Ibidem, p. 126.

${ }^{36}$ bandiś - lit. "composition”, "structure", "tying”, "limitation”, "a pattern (of music)".

${ }^{37}$ bol banā $v$ - musically conveying the same sentiment as the words convey.

${ }^{38}$ N. Joshi, Compositions of Maharaj Bindadin, "Sangeet Natak Akademi Bull." 15-16, April 1960, p. 34 . 
elaboration of the text through vocal, abhinaya, gestures and movements. Therefore, the art of thumri can be fully appreciated only on stage, where the performer can extract the multiple layers of meanings. This polysemy is not limited to the aforementioned śrngāra theme, but also occurs in other, secular motifs. We can point to it in the exemplary thumri, ascribed to Wajid Ali Shah:

Father, I'm leaving my parental home.

The palanquin is lifted by four (water-)carriers

What's mine, what's not mine - it's all left behind. ${ }^{39}$

There are at least three possible interpretation of this song. Literally, the lyrics speak of a bride, leaving her home in a palanquin. On a symbolical level, it can depict a funeral procession. On a different political level the thumri evokes the historical moment of the annexation of Oudh by the British colonisers, who forced the nawa $b$ to leave Lucknow and move to Kolkata ${ }^{40}$. The event is invoked in another thumrì ascribed to the nawāb:

At the time of leaving Lucknow,

After what happened to Ali

In every palace a begum was weeping

As I depart, the world passes away. ${ }^{41}$

The motif of separation is articulated from a female perspective, in relation to a precisely indicated lover - a secular patron, a nawāb himself, who is both the author of the lyrics, and an addressee of the love message. The vocabulary reflects the reality of his court and harem, called "the palace of fairies" (parīyom kā khānā).

Go Fairy, bring Wajid Ali Shah

I will be your handmaiden then

Nothing is pleasing without Akhtar Piya ${ }^{42}$

Take my news [to him].43

${ }^{39}$ bābul morā naihar chūṭo jay / cār kahār mili ḍoliyā uṭhāe / apna bigānā chūṭo jay (P. Banerjee, Dance in Thumri, New Delhi 1986, p. 25.), transl. by author.

$4^{\circ} \mathrm{V}$. Sampath, My Name is Gauhar Jaan: The Life and Times of a Musician, New Delhi 2010, p. 107.

${ }^{41}$ jab choṛ cale lakhnaū nagarī / tab hāl-i alī par kyā gujarī / mahal mahal mẹ̣ begam rove / jab ham gujare duniyā gujarī (P. Banerjee, op. cit., p. 33), transl. by author.

$4^{2}$ Pen name of Wajid Ali Shah.

43 jā tū parī vājid alī sāh ko lā de / hoūṃgi terī cerī re / akhtar piyā bina kuch nahīṃ bhāve / le jā sandeś hamāra re (Ibidem), transl. by author. 
The thumrīs attributed to Wajid Ali Shah use many conventional motifs from old Indian literature (both Sanskrit and "folk"), such as the figure of a messenger, or a storm, disturbing the heroine on her way to her beloved. The sensual aspect of viraha seems to be overwhelming, due to overt allusions to a sexual reunion.

Lightning keeps flashing,

How can I reach your bed, oh Dear?

Thunder roars, heart suffers (shakes in fear)

I had sent news to Akhtar Piya. ${ }^{44}$

Some songs have a personal, romantic tone, sometimes overtly erotic, exposing a woman's desires, emphasised by suggestive abhinaya in a performance. More sensual depiction of viraha appears in thumrīs ascribed to courtesans, like Begam Akhtar (who was also skilled in dance).

You woke me up from my dream.

When I was young and unripe

my lover took me to his village.

Now, when I'm passionately missing him,

he has gone to a foreign land. ${ }^{45}$

Nature is often the witness of the heroine's state of mind. Natural phenomena, like rain, singing of birds, or changing seasons, intensify her moods:

The season of rain is my enemy.

Clouds roar in the month of Asarh

My beloved has gone to a foreign land.

The peacock, papiha, frog, and chatak twitter.

Friend, I cannot stand the pangs of separation now,

As if my heart is broken. ${ }^{4}$

${ }^{44}$ camak camak camke bijariyā / kaise ke āūm piyā torī sejariyā / bādar gajre jiyarā tarse (larje) / akhtar piyā sang bhejī khabariyā (P. Banerjee, op. cit., p. 32-33; Maya Tak, Thumri aur kathak nrtya, p. 98), transl. by author.

${ }^{45}$ sovat nind jagāe ho / jab maim rahlī bārī na bhārī / tab saīyān lā gavan / jab maim bhal bār taras ke / tab saīyān calā bides (P. Manuel, Thumri in Historical..., p. 22), transl. by author.

${ }^{46}$ barṣa rūt bairī hamāre / mās asāṛh ghațā ghana garajat / piyu perdes sidhāre / mor, papīhā, dādar, cātak, piyu piyu karat pukāre / ab na sahat sakhi catur birah duhkhh nikarat prān hamāre (P. Banerjee, op. cit., p. 48), transl. by author. 
Similar imagery of a messenger and nature in the depiction of viraha can be found in the Bindadin thumrìs. The addresser of a love message is often Syām - "the Dark One"- a term that recalls an association of Krishna, bringing the poem to a more metaphorical, devotional level.

May someone go and convey the message:

Since he has gone, he hasn't even asked about me

I cannot stand the arrow of separation

I passed rainy season without seeing you

Binda, I cannot live without meeting Śyām

May someone go and tell (him). ${ }^{47}$

Some courtesans also took the perspective of Radhika in the performance. An example is a thumrī, sung by a Muslim courtesan, Gauhar Jaan:

O traveller, just tell Girdhāri (Krishna) when you see him

That Radha has no more tears, has he forgotten Braj?

Come to me Sāmvariy $\bar{a}^{4}$, let me embrace you

Your eyes are full of liquid

Whomsoever you gaze upon, you control

I can find no peace...

Your eyes are full of liquid. ${ }^{49}$

A similar motif of charming eyes, which takes away the whole peace and dream of a mistress, is found in a thumrī created by a male, Muslim composer, Saeed Khan:

Your eyes are full of charm

(I have) no sleep at night, no peace in the day

I toss and turn, day and night..$^{0}$

47 jāy kou kahāṃ, jāy itnā sandeśvā koī kaho / jabse gaye morī sudh hū na līnī / birahā ke bān ham se nā saho/ barsan jo bīte daras bin / bindā bin mile Syām hamse nā raho / jāy koì kaho (Ibidem, p. 45-46), transl. by author.

$4^{8}$ Sāmvariy $\bar{a}=$ "one with dark skin" (Krishna).

${ }^{49}$ are pathik girdhāri sun itni kahiyo ter / dig jhar layi rādhika ab brij bhūlat pher / ā ja sāṃvariya tohe garava lagā do / ras ke bhare tore nain, sāṃvariyā / ras ke bhare tore nain / jehi chitavat tehi bas kari rākhat / nāhi pade maika cain sāṃvariyā / ras ke bhare tore nain (V. Sampath, op. cit., p. 283; L. du Perron, Hindi Poetry..., p. 168), transl. by author.

${ }^{50}$ tore nain jādū bhare / rāt nahīm nindiyā din nahị̣ cain / talpat hūṃ din rain (Text and transl.: L. du Perron, Hindi Poetry..., p. 155). 
Another thumrī by the same poet recalls the scenery of Braj region, indicating Krishna as the reason for viraha. The thumri was often sung by Shambhu Maharaj, who generally favoured Khan's compositions over Bindadin's (his uncle) songs. He found them more proper for a longer elaboration of abhinaya, so that he could develop the first verse over an extended period:

In which alley has Śyām gone?

I've searched Gokul, I've searched Brindaban

I've searched all over the four pilgrimage sites,

Oh dark one, Oh my love..$^{1}$

As may be noticed, the motif of viraha in the old corpus of thumrī often uses the figure of Krishna and gopi, drawn from Vaishnava metaphoric. Whether it had been performed by a Hindu bhakta, or a Muslim courtesan, most thumrīs present an image of a woman longing for union with her beloved. She has no peace, cannot sleep, thinking of him day and night, as if he has cast a spell on her. The ambiguity of viraha provides a space of double meaning through which the performer could negotiate his/her own identity: as a devotee, as a women in love, or as a seductress. Vidya Rao explains the parallel ambiguity of the songs, sung by courtesans and other performing communities, in various contexts:

... the immediate performing context, the identity of the performer, as well as that of the listeners, determines its intension, inflection, and reception. The same Dadra sung by a tawaif in a Mujra, or by the same tawaif at an urs festival in the dargah or shrine of a sufi saint is, each time, inflected differently. Sung by a 'modern' artist, at a sammelan, or sung at the mehfil by a male ustad - the Dadra reveals different meanings and possibilities of reception..$^{2}$

In fact, the Muslim tawä'if s sometimes took Hindu names, probably when they performed for Hindu spectators. Similarly, they could elaborate the rāslìla theme, merely as an aesthetic motif, without any intention to raise religious feelings. This approach is still shared by some Muslim exponents of

${ }^{51}$ kaun galī gayo Śyām / gokula ḍhūṃ̣hī brindāban ḍhūṃ̣hī / ḍhūṃ̣̣h phirī carauṃ dhāma / sāvariyā saiṃyāṃ (Text and transl. L. du Perron, Hindi Poetry..., p. 139).

${ }^{52} \mathrm{~V}$. Rao, Thumri and Thumri Singers. Changes in Style and Lifestyle, p. 285. 
kathak. For instance, Rani Khanam perceives the theme of rās-lìlā as an integral part of kathak tradition, and does not refrain from the artistic development of this motif. ${ }^{33}$ Such an attitude can also mirror the formerly existing fluidity of cast and religion, especially in terms of artistic creativity. The thematic scope was circulated among various communities. Certain conventions of presenting the motif are still reproduced by contemporary artists. In the following example of viraha, in the thumrī composed by Jaykishan Maharaj, one can notice recurrent metaphors, similes, conventional motifs and phrases, known from the old corpus of texts.

I have no peace without you, Samvariy $\bar{a}$

How to pass this night without you?

I have no peace without you

My uneasy heart struggles night and day

I never find contentment

Days and nights I am staring at the road, hoping to see you there

My eyes are petrified

I have no peace without you

My mind is agitated by the separation

There is nothing pleasing at the courtyard of my house

Servant, I am beside myself with weeping

Eyes are yearning to see you

I have no piece without you. ${ }^{54}$

Some of the songs present the traditional topic in an innovative way. For instance, Jaykishan Maharaj has juxtaposed the two leading thumrī motifs of viraha and cher-chār(teasing of gopiss) in one song. Longing for reunion with Krishna, a gopi recollects all his mischievous deeds and pranks that constitute a motif of cher-chär:

Since he has gone, he has not taken account of me

Why he does so for my love?

\footnotetext{
${ }^{53}$ Rani Khanam, pers. conv., New Delhi, April 2, 2015.

54 bin tore nāhī cain saṃvariyā / kāse kațe tere bin ye rain / bin tore nāhī cain // vyākul manvā tarpat nisadin / kabhuṃ na pave cain / bāt takūṃ nis din maiṃ torī / pathrāye more ye nain / bin tore nāhī cain // virah se vyākul morā manvā/ mohe nā bhāve ghar āṃnavā / dās ye āṃsū ro ro hāre / dekhan cāheṃ nain / bin tore nāhī cain (J. Maharaj, Mādhurya vol. I, n.d.), transl. by author.
} 
Who will stop me on the way now?

Who will break my water jug now?

Who will disturb my daily routine?

My agitated heart finds no calm

Since he has gone, he has not taken account of me

Listen to me, oh flute, I will never rival with you

Even if you stay forever with Mohan

Servant, I am spiritless without Krishna,

I only hope / desire to meet him

Since he has gone, he has not taken account of me. ${ }^{55}$

\section{When a woman says no...}

The motif of cher-chār prevails in the thumrīs ascribed to Bindadin Maharaj. These songs illustrate a number of scenes: Holi celebrations, love of Krishna and Radha, gopīs' yearning for Krishna. Some of the songs are composed in pairs (jora), demonstrating the complex, emotional states of the cowherdesses. While in first part they are teased by Krishna, in the second part, they take a role of the aggressor. ${ }^{56}$ This is exemplified in a thumri depicting the motif of panghat - women walking with a pot to the riverside, or a well. Krishna often disturbs them and harasses them on a way - breaking their pot by throwing a stone, pulling their veil, holding their hands, etc. One day, in revenge, the gopis grabbed Krishna and made fun of him, dressing him as a woman.

See, Śȳm was walking down the road,

As I was going to fetch water

I saw naughty Śyām there

He was looking and smiling mischievously, disturbing my mind

Suddenly he came and jerked my veil

He embraced me and grasped my body

Walking down the road...

55 jab se gaye morī sudh hu na līnhī / kāhe aiso prìt ve kīnhī / koū roke ab morī dagariyā / koū phoṛe ab morī gagariyā / koū ab nit kī rār macāe / vyākul manvā dhīr na pāe / jab se gaye morī sudhhu na linhī // sun bansī tose kabahu na laṛibe / cāhe sadā mohan sañg rahibe / kṛṣn binā dās kachu nāhi / âs milan kī abhī hai bākī / jab se gaye mori sudhahu na līnhī (J. Maharaj, op. cit.), transl. by author.

${ }^{56}$ N. Joshi, op. cit, p. 33. 
Let's seize Krishna today, and make him a woman,

Let's give him nose rings and plait him a braid

Let's put a bindi on his forehead and dress him in a sari

Binda says: he spreads miraculous beauty. ${ }^{57}$

Krishna teases the gopis of Brindavan, especially when they go to the bank of Yamuna, to fill water-jugs. He also steals their clothes when they bathe in the river. The spring celebration of the Holi festival provides another opportunity for men to harass girls. These scenes are depicted in a sub-genre of thumrī, called horì.

How can I go to Jamuna to fetch water?

the sounds of tambourine, mridang and vina are reverberating today Braj celebrates Holi, Nand is playing (red) colours with gopīs

He rubs red powder into their faces, he shakes their limbs violently

He embraces them and kisses them forcibly

Binda, today $\bar{S} y \bar{a} m$ is surrounded by gopīs. ${ }^{58}$

The motif of cher-chār usually illustrates a situation, in which a woman is afraid that her reputation might be ruined because of the indecent behaviour of her lover. Radha is married, so she has to hide her true love feelings for Krishna, especially in front of the other villagers and her family members. Therefore, she rebukes Krishna, even though, deep in the heart, she is happy about meeting him.

All the men and women are looking,

you have no shame

Why are you always leering so?

57 ḍagar calat dekho śyām kar gaiyām / nīr bharan maim gaī panghat ko / dekhyo tahāṃ śyām naṭkhat ko / haṃsyo nirakh mere man khaṭkhyo / āe acānak cūnar jhaṭkyo / gare lagāe līnhī mohe kaniyām / ḍagar calat... // gaho kṛ̣̣n ko jāne nā pāvem / inhem àj ham nārī banāveṃ / nath (nakh) besar sir coṭī guṃthāvem / bendī bhāl sārī pahnāveṃ / binda kahat agbhut chavi baniyām / ḍagar calat... (B. Maharaj, Ras gunjan: Maharah Bindadin ki rachnayen, Bombay 1994, p. 30), transl. by author.

${ }^{8}$ jal jamunā bharan kaise jāūṃ āj / macī dhūm bajat ḍhap mṛdang bīn / khele nand ko lāl horī braj mẹ̣ āj / mukh mīje bhal rorī ang det jhakjhorī / gahi garvā lagāye munh cūme bārājorī / binda śyām gher lino sakhin āj (N. Joshi, op. cit., p. 35), transl. by author. 
I have to go now, I will meet you at night, we will stay together and I'll listen to you

Let me go home, and come at night,

If my mother-in law hears us, she will abuse me. ${ }^{59}$

As noted by Manuel, the scenes of meeting a beloved in secret can reflect folk life reality, in which arranged marriages were an obstacle for truelove relationships. The beloved is usually referred by piyā, bālam, saiyyān, or sajjan - which are all ambiguous terms, meaning both a husband and a lover. ${ }^{60}$ When he is addressed as śāma, ghan, girdhāri, kānha, hari, manmohan, or rasiya - , the identification with Krishna is clear. The exhortation of a heroine may be also subversive, depending on punctuation that is blurred, or manipulated in a performance:

Don't touch me, don't touch me, don't touch me, my dear / Or:

Touch me, won't you?

Let go, let go, don't break my bangle.

All my sisters-in-law will argue with me.

All the women of Braj will scold me.

Why did you tear my sari? Leave my amcāl! ${ }^{61}$

Depending on where the coma falls, we can consider two possible interpretations of the phrase ${ }^{62}$ :

mohe cheṛo mat, jāo saīyān = Don't tease me, go away, dear mohe cheṛo, mat jāo saīyān = Tease me, but do not leave me, dear

The negative Hindi particles mat or $n a$ can be placed both before and after the conjunctive verb, so a comma clarifies the conjunction when there are two verbs in the same line. The modulation of voice and abhinaya can add a lot to the meaning of words. There are often no comas in the text, so the message shall be decoded in reference to other verses. For example, the general message in the following thumri of Birju Maharaj, can suggest perverse incentive on the part of a gopi:

${ }^{59}$ sab hī nār-nārī dekhat / lāj na āve, nit uṭh kahe ko muskyat, aisi / ab kī jāne de bāt, milūṃgī rāt, rahūṃgī sāth, sunūṃīi bāt / ghar ko jāne de, ratīya āne de, / sān sunegī to degi gālī (P. Manuel, Thumri in..., p. 18), transl. by author.

${ }^{60}$ Ibidem, p. 15.

${ }^{61}$ nā chero nā chero nā cheṛo saimyām / chạro chāro kangganāvā morā nā toṛo / mose laregī daurānī nanada jiṭhānī / sārī braja nārī maiṃko degī gārī / kāhe phārī sārī chāra de ạ̣carā morā (L. du Perron, Hindi Poetry... , p. 190), transl. by author., amcā $=$ = the endpiece of sari

${ }^{62}$ Ibidem, p. 191. 
Touch Śyām do not grasp my arms

I may forget myself (lose consciousness/purity) when I come toward you

my body shudders, my caution is stricken with fear

I experience unknown pleasure

Touch, touch body, irrigate mind

stay in my eyes, do not leave mind

I am frightened without Brijśyām, oh Friend

I spend a night, palpitating in agony. ${ }^{63}$

\section{$6 \quad$ Kathak and nāyikā-bheda}

Some artists and theorists stress the relevance of the depiction of heroines in kathak and thumrī to the eight types of heroines (skt. aștanāyikā-bheda), described in the Nātyaśāstra ${ }^{64}$. The classification of thumrī themes according to a model of astanayik $\bar{a}-b h e d a$ is propagated by singers like Naina Devi and Rita Gangooly. ${ }^{65}$ Many writers (Projesh Banerjee, Madhukar Anand, C. Jyotishi, Anita Sen, P. Manuel) also describe kathak repertoire and thumrī in reference to this classification, attributing a specific type of $n \bar{a} y i k \bar{a}$ to a particular song. Such categorisation of thumrī is, however, problematic. There is an absence of some types of nāyikās in thumri, and some of the depicted heroines do not easily conform to a particular type of nāyika from Nātyaśāstra. The portrayal of a mistress can be convergent with a few of these types since in one composition, a heroine could experience several emotional states.

Jyotishi reveals that senior gurus were not acquainted with shastric nomenclature and classification, and used their own descriptive terms in Hindi to refer to a depicted heroine. They illustrated a wider variety of female features, including age and social status. From the several typologies of heroines

${ }^{63}$ chẹ̣o śyām na pakrom baṃịmyā / apni sudh bisrāūm / kachu kachu lāgat ajūbo kānhā / jab tore dig jāūm / sihrat ang sajag hoye kampit / anjānā sukh pāūm / chẹ̣ chẹ̣ tan man ko sīṃco / dhan dhan kahi bali jāūṃ / nayan baso chợo na man ko / jāsoṃ maiṃ dukh pāūm / ḍarpat hūṃ bṛjśyām binā sakhi / tarpat rain bitāūṃ (M. Anand, Kathak kā Lakhnaū gharānāa aur Pt. Birjū Mahārāj, New Delhi 2013, p. 137-138), transl. by author.

${ }^{64}$ See NŚ, XXII, 211-212 ff. (according to the edition Nātyaśāstra of Bharatamuni with the commentary Abhinavabhāratī by Abhinavaguptācārya, vol. II, Parimal Sanskrit Series No. 4, Parimal Publications, Delhi 1988.

${ }^{65}$ P. Manuel, Thumri in Historical..., p. 10. 
described in Nātyaśāstra, contemporary kathak artists and theorists refer almost solely to the aștana $y i k \bar{a}$ bheda - indicating mostly the states in which a woman finds herself in relation to her lover. Such a selection of motif may be explained by the fact that these criteria seems to be the most neutral, and suitable to the puritan tastes of modern audiences. Other classifications included in Nātyaśāstra, based on social background, age, temperament, natural (sexual) disposition, or the manner in which the king treats the ladies of his harem, seem to be avoided in kathak.

Nowadays, only four types of heroine (khanditā - "one enraged with her lover", abhisārikā - "one going to secretly meet her lover", virahotkanthit $\bar{a}$ - "one distressed by separation" and rūpagarvita - "one proud of her own beauty") are presented in thumrī dance performance. ${ }^{66}$ Students of Kathak Kendra are taught only these songs, expressing the feelings of a young girl ( mugdha) , characterised by modesty, purity, shyness, sweetness, and physical charms. The classification does not emphasise the four stages of youth specified in Nātyaśāstra in terms of sexual attributes (lips, cheeks, thighs and breasts), temperament and level of excellence in sexual intercourse. There are also no depictions of gaṇikä/samānya (prostitute or courtesan) in kathak. Elder women, or courtesans, are often depicted in literature as proud and aware of their sexual charms, and these features might have been regarded as unsuitable for a chaste woman to enact.

The pangs of unrequited love are considered to be a better theme for long elaboration than the joys of union, which are almost absent from thumri verses (especially in bol banā $v$ thumrī). Manuel argues that the dominance of viraha in thumri may reflect the generality of such circumstances in social reality, where lovers are often separated for economic reasons, arranged marriages, customs, or lack of privacy for themselves in a house. ${ }^{67}$ Illegal love (such as between Krishna and Radha) can be idealised as being more true. Courtesans in particular explored this theme, as they rarely entered into formal relations with their beloved.

Apart from the state of separation, there are other kinds of unrequited love, depicted in thumri and kathak, which are also reinterpreted according to the nāyika typology.

Why have you come to my house

Having spent the night with co-wife (my rival)

${ }^{66}$ C. Jyotishi, op. cit., p. 130.

${ }^{67}$ P. Manuel, Thumri in Historical..., p. 17. 
Your red-tainted eyes tell lies

Don't fall at my feet for forgiveness

Go and stay at her abode

Don't talk to me

Binda says, I am burning within, but

He doesn't pay attention. ${ }^{68}$

This imagery resembles an image from khanditi $n \bar{a} y i k \bar{a}$ - a heroine angry with her lover, after discovering his infidelity. An ideal heroine is expected to reproach her beloved with anger that metaphorically means her total subordination to God. When a married heroine secretly goes to meet her lover, it is also automatically understood as a metaphor for the soul, as outlaw relationships are socially unrespectable, so only such an interpretation is acceptable for a modern Indian audience.

As the exact shastric framework has been introduced into kathak by new kinds of performers, the illustration of the particular emotional state of a heroine seems to correspond more to the Sanskrit aesthetic conventions. Moreover, the visual depiction of the lyrics on stage often resembles popular representations of the $n \bar{a} y i k \bar{a}$ motif in Indian miniature paintings (see picture 3).

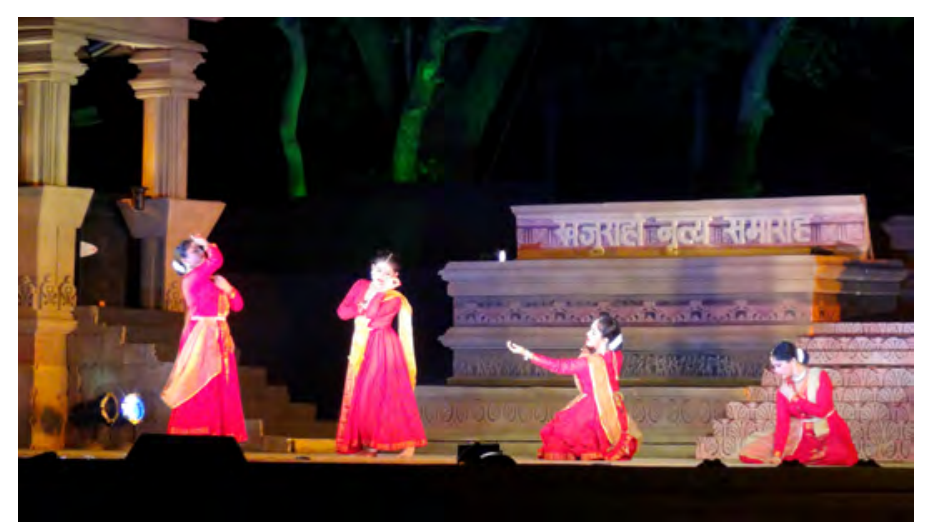

Figure 3: Rani Karna Group presentation of the various emotional states of the heroine $(n \bar{a} y i k \bar{a})$ in the Khajuraho Dance Festival 2015 (photo by author).

${ }^{68}$ kāhe ko mere ghar āye ho / prītap tum rain sohat sang jāge / nainā ratnāre / paiyāṃ na paṛo ab pyāre kāhe ko / unhī ke ghar raho / jāvo nahịm bolo mujhse / bindā suno nahịm yah mane / jiyā jāre, kāhe ko. (N. Joshi, op. cit., p. 37), transl. by author. 
An example is a thumrī created by Jai Kishan Maharaj, illustrating the motif of a heroine on her way to meet her lover, modelled on the abhisārikā type:

In the madness she goes to see her beloved

She puts a bindu on her forehead, earrings, and garland on her neck

anklet on her feet, bracelets on her hands.

The thought of reunion with her lover makes her smiling inside

In the madness she goes to see her beloved

Furtively, hiding herself from all those who are awaken

Opens the door with trembling heart

The passionate woman takes a lamp in her hand

In the madness she goes to see her beloved

Seeing flashing lightings, torrents of rain,

And darkness, her heart is beating laud

A venomous snake crosses her way

Servant, she got pierced by thorns,

In the madness she goes to see her beloved. ${ }^{69}$

Such an application of Sanskrit aesthetic theories reflects the efforts to standardise kathak, especially in accordance with the Nātyaśāstra rules. In $k a t h a k$, the reinterpretation of śrngāra in terms of bhakti went hand in hand with the "sanskritisation" of the dance. Analogous initiatives for incorporating rules from Sanskrit aesthetic theories can be noticed in the course of thumrī modernisation, aimed at disassociating the genre from koth $\bar{a}$ 's culture, and bringing its respectability to the national stage. In fact, many conventions that seem to originate from Sanskrit aesthetics could have equally been imported from folk tradition, such as the motif of viraha. Hereditary performers incorporated a variety of songs from the regional, village repertoire.

The main language of thumri is Braj bhasha - a leading dialect of old Hindi poetry, spoken in North India, associated with the Krishna bhakti

${ }^{69}$ piyā milan so calī bāvarī / bendī bhāl kuṇụal gae mālā / pag nūpur kar kangan ḍāā piyā basāy hiya mand muskāī / piyā milan so calī bāvarī // sab jag jan se corī - corī / kāṃpat man kivār jab kholī / kar dīpak lai calī bhāminī / piyā milan so calī bāvarī // camkat dāminī mūsal barse / andhakār dekhi jiyārā dhaṛke / dekhi āge calī panth viṣadhārī / dās kaṇțak cubhi jhukī nikārī / piyā milan so calī bāvarī (J. Maharaj, op. cit.), transl. by author. 
cult, in which music was an important form of worship. As thumrīs were composed by Urdu-speaking musicians in Lucknow, there are also Urdu and Khari-boli elements in the language of these songs. Its style represents a confluence of urban/classical and rural/folk traditions. As pointed out by Jyotishi, the abhinaya remained closer to folk symbolism than to shastric codes of expressions, which makes the dance more comprehensible for the masses. ${ }^{70}$ In the opinion of Manuel, although the majority of thumrīs were written during or after riti period of Hindi literature, they do not mirror its predominant over-emphasis of Sanskrit poetics and mannerism, because their composers partly Muslims - were not well-acquainted with Sanskrit aesthetics. We can notice some influence of Sanskrit theory on the modes in which the heroines are depicted and the bhavas are defined, but it might equally be an outcome of the later "sanskritisition" of the genre.

The intensions of revivalists and non-hereditary artists to some extent must have influenced hereditary communities, who needed to conform to new standards of classical performance, such as time restrictions or a larger space (to be covered by many dancers). Some senior gurus attempt to resist these tendencies. The account of Mohan Khokar reveals that Shambhu Maharaj - the first kathak guru in Bharatiya Kala Kendra - seldom performed to Bindadin's thumrīs, but mostly to Naseer Khan's compositions. But the new generation performs to Bindadin's compositions, probably because of its suitability for rendering in a moderate tempo. Shambhu Maharaj valued an elegant development of bhava, also in a sitting position. For that, he found Bindadin's thumrīs too fast..$^{71}$ Furthermore, he shared a sceptical attitude toward many ongoing changes in kathak, such as increasing the tempo of the dance, abhinaya devoid of real flavour, dancers who do not sing themselves, or group choreographies ("ballet-shallet" as he called it). He regarded these new fashions as heralding the end of tradition: "The Kathak I dance is brewed in a heady atmosphere of poetry, women and wine and that milieu is lost" he once said (in an interview with Mohan Khokar) ${ }^{72}$. Similarly, other artists pointing to the lack of abhinaya skills among the new generation of artists deplore that traditional kathak is slowly disappearing. ${ }^{73}$

In the course of kathak revival, the scope of repertoire was also signific-

${ }^{70}$ C. Jyotishi, op. cit., p. 114 .

${ }^{71}$ A. M. Khokar, Kathak Samrat Shambhu Maharaj, "Nartanam” Vol. 12, no 3, 2012, p. 32.

${ }^{72}$ Ibidem.

73 Sunayana Hazarilal, pers. conv., Mumbai, February 14, 2014; Uma Sharma, pers. conv., New Delhi, March 27, 2014. 
antly broadened. Senior kathak artists who learned kathak in newly opened dance academies, like Bharatiya Kala Kendra in the 1950s, confess that their guru (Shambhu Maharaj) used to teach them compositions limited to Krishna stories, especially the motifs depicting his pranks and flirtation with gopis, or harassing them during Holi celebrations. ${ }^{74} D \bar{a} d r \bar{a}$ and thumri were the two main poetic genres through which the stories were conveyed..$^{75}$ Since the 1950s, the devotional component has been extended to include songs of praise (stūti, śloka), or invocations (vandanā) to various Hindu gods (Rama, Shiva, Ganesha, Saraswati, Kali-Durga). Furthermore, the bhajans of famous bhakti poets started to be sung along with kathak.

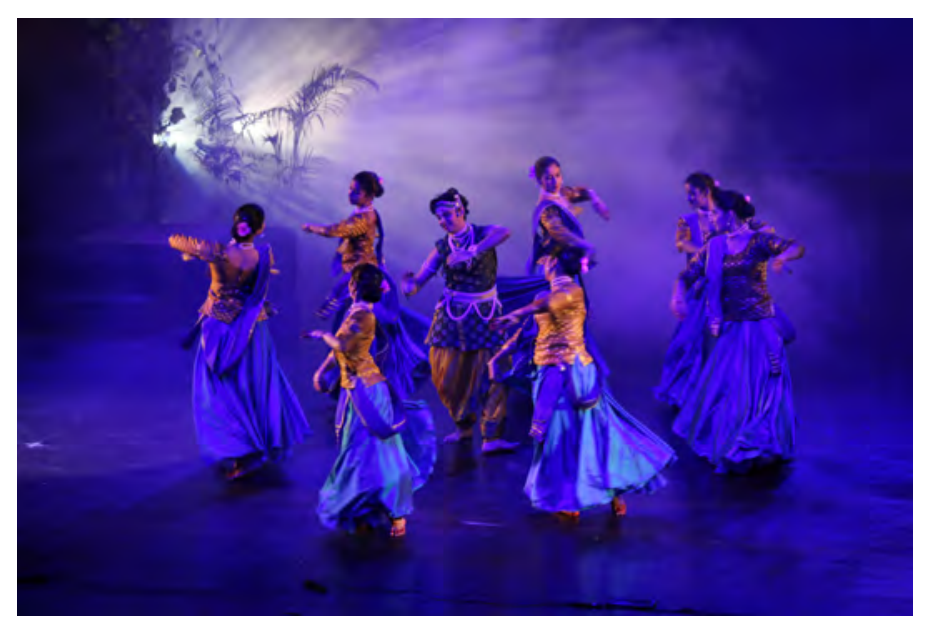

Figure 4: A group choreography of rās-līlā theme (Krishna dancing with cowherdeesses) by Jai Kishan Maharaj Group, New Delhi 2015 (photo by author).

A typical, contemporary kathak performance consists of various rhythmical and narrative compositions, illustrating narratives from Sanskrit epics and puranas. The majority of songs deal with Krishna mythology - rāsa-līla in particular - but the emphasis on group choreographies seems to be growing (see picture 4). Besides the Krishna's dalliance, popular episodes from his life often illustrated in kathak include: little Krishna's stealing of butter

${ }_{74}$ Kumudini Lakhia, pers. conv., Ahmedabad, February 20, 2014; Maya Rao, pers. conv., Bangalore, January 27, 2014, Uma Sharma, pers. conv., New Delhi, March 27, 2014.

${ }^{75}$ Apart from thumrī, nāyikā-bheda motif was illustrated through dhruvapada, dhamāra, hori, and cāncar. 
(mākhana-corì), the killing of Putana (pütana-vadha), Radha and Krishna in a swing (jhüla), Holi celebrations (horì), the stealing of clothes (cira-harana), raising the mountain (govardhana-lìla), the subduing of the demon-snake Kaliya ( $k \bar{a} l i y \bar{a}-d a m a n a)$, the unrobing of Draupadi's sari (draupadi vastraharana). Apart from Krishna, other deities are portrayed, especially Rama, Shiva and Kali-Durga. Sometimes, ten incarnations of Vishnu are presented in one longer composition called daśāvatāra. Besides, there are numerous adaptations of kāvya literature, such as Mālatī-Mādhava, Kumāra Sambhava, Gìtagovinda, and of classical Sanskrit dramas (ascribed to Bhasa, Kalidasa). The new generation of choreographers interpret various poems in Hindi, Urdu, Bengali, and other South Asian languages, as well as "ballets" on various historical, social, and abstract subjects.

\section{Conclusions}

This short overview of the thumrī reveals how suggestive and ambivalent the language of these songs can be, generating various possibilities of interpretation. An outcome of the confluence of different traditions (court and folk), the genre makes use of numerous wordplays and suggestive images, so that a performer can oscillate between modesty and obscenity, depending on how she or he enacts the lyrics. There were poems from the old corpus, presenting secular themes, but many of them have disappeared in the course of transmission to the modern stage. If we take into consideration to whom the songs and dance were addressed in nineteenth-century Lucknow, we may assume that they were meant to evoke erotic sentiments, rather than religious feelings. On the other hand, male masters used to teach tawa' 'if s more seductive movements and gazes, different from what they taught their own sons. Taking a female perspective is not unusual in bhakti traditions. The nature of śrngāra could oscillate between the erotic and the devotional, depending on the context of the training and performance. The social circumstances of the dance is thus a decisive factor in determining the dominant message, which is often multi-layered within the poem itself.

Since the 1950s, the relocation of the art from courts and red-light districts to national stages and festivals has triggered a considerable shift towards devotionalism - both in the art of thumri and dance. This emphasis on spiritualism still seems to be dominant in kathak. It can be reflected in the thumrīs composed by Birju Maharaj and his son Jai Kishan Maharaj. The 
recently published collection of Jai Kishan's compositions entitled Madhurya contains a number of thumrīs, bhajans, kavitts and other kind of lyrics termed as jhūlā, viraha, stuti, Mìrā. The thematic scope of the thumrìs remains a motif of pranks and separation. The difference lies in the chap (the name of the author inserted in the lyrics) - instead of the poet's name, the term $d \bar{a} s$ ("a slave", "a servant") is used, explained in commentaries as signifying both Radha, and a poet. Thus, there is a clear identification of the author with a female agent, a metaphor of bhakta ("a worshipper"), placing the whole picture of $r \bar{a} s-l \bar{l} l \bar{a}$ in a devotional context.

Vidya Rao points out that thumri, to some extent, has resisted nationalist projects of appropriation and, therefore, it has fallen lower in the hierarchy of Indian music - as a semi-classical genre. It was not relevant to be a vehicle of heroic taste, and the dominant śrngāra still reverberates the echo of thumrī's past. To disguise this link, some songs were dropped from the repertoire, while others were reinterpreted in terms of bhakti. The erotic mood was covered by the purdah of technical virtuosity. ${ }^{76}$ Eye-contact between the viewer and the performer has also disappeared. To further "purify" (desexualise) the performer's body, multiple means of expression have been limited. In the view of Rao, since bodily expression have been replaced by vocal modulations, the performance of thumrī has lost much of its emotional power. "By such an amputation, by making Kathak and Thumri separate forms, both suffer a viraha, a separation that weakens them to the point almost of death" ${ }^{77}$ Nevertheless, at least both art forms have survived the Anti-nautch propaganda and, in its modern reincarnations, continue to touch the hearts of many music and dance lovers.

${ }^{76}$ V. Rao, op. cit., p. 311.

${ }^{77}$ Ibidem, p. 305. 


\section{Bibliography}

1. Allen M. H., Rewriting the Script for South Indian Dance, "The Drama Review", vol. 41 No 3, 1997, pp. 63-100.

2. Anand M., Kathak kā Lakhnaū gharānā aur Pt. Birjū Mahārāj, New Delhi 2013.

3. BAKhle J., Two Men and Music. Nationalism in the Making of an Indian Classical Tradition, New York 2005.

4. Banerjee P., Dance in Thumri, New Delhi 1986.

5. Chakravorty P., Bells of change, Calcutta 2008.

6. Damayanti foshi: Manaka's Daughter, Materials of Sparrow, 1998.

7. Du Perron L., Hindi Poetry in a Musical Genre: Thumri Lyrics, London 2007.

8. Du Perron L., The Language of Seduction in the Courtesan Performance, [in:] Music, Dance and the Art of Seduction, eds. F. Kouwenhoven and J. Kippen, Delft 2013.

9. GARg L., Kathak nrtya, Hathras 1969.

10. Joshi N., Compositions of Maharaj Bindadin, "Sangeet Natak Akademi Bull.", April 1960.

11. Jyotishi C., Nayika Bheda in Kathak, Delhi 2009.

12. Khoкar A. M., Kathak Samrat Shambhu Maharaj, "Nartanam", Vol. 12, no 3, 2012, pp. 28-35.

13. Kothari S., Kathak: Indian Classical Dance Art, New Delhi 1989.

14. Maharaj B., Ras Gunjan: Maharaj Bindadin ki Rachnayen, Bombay 1994

15. Maharaj J., Madhurya, vol. I. (n.d.)

16. Margiel N., Eros and Shame in North Indian Art Music, [in:] Music, Dance and the Art of Seduction, eds. F. Kouwenhoven and J. Kippen, Delft 2013.

17. Manuel P., Thumri in Historical and Stylistic Perspectives, New Delhi 1988.

18. Manuel P., Thumri, Ghazal, and Modernity in Hindustani Music Culture. [in:] Hindustani Music: Thirteenth to Twentieth Centuries, eds. J. Boer, F. Delvoye, J. Harvey, and E. Nijenhuis, Delhi 2010, pp. 239-252.

19. "Nātyaśāstra of Bharatamuni with the commentary Abhinavabhārati by Abhinavaguptācārya”, vol. II, Parimal Sanskrit Series No. 4, Parimal Publications, Delhi 1988. 
20. Rao V., Thumri and Thumri Singers. Changes in Style and Lifestyle [in:] Cultural Reorientation in India, eds. Indu Banga and Jaidev, Shimla 1996, pp. 278-315.

21. Snell R., The Hindi Classical Tradition: A Braj Bhāṣā Reader, London 1991.

22. Sampath V., My Name is Gauhar Jaan: The Life and Times of a Musician, New Delhi 2010.

23. Walker M., Kathak Dance: A Critical History, unpublished Ph.D thesis, Toronto: University of Toronto, 2004.

24. Walker M., Wounded with the Arrow of Her Eyelashes: Seduction and Sensuality in North Indian dance [in:] Music, Dance and the Art of Seduction, eds. F. Kouwenhoven and J. Kippen, Delft 2013.

\section{Interviews/consultations}

- Busch, Allison, pers. conv., New York, February 23, 2016.

- Chakravorty, Pallabi, pers. conv., Swarthmore, February 17, 2016.

- Hazarilal, Sunayana, pers. conv., Mumbai, February 14, 2014.

- Khanam, Rani, pers. conv., New Delhi, April 2, 2015.

- Lakhia, Kumudini, pers. conv., Ahmedabad, February 20, 2014.

- Maharaj, Birju, pers. conv., New Delhi, February 18, 2015.

- Manuel, Peter, pers. conv., New York, February 24, 2016.

- Mishra, Arjun, pers. conv., Lucknow, April 11, 2015.

- Rao, Maya, pers. conv., Bangalore, January 27, 2014.

- Sharma, Uma, pers. conv., New Delhi, March 27, 2014.

The project was funded by The National Science Centre $(\mathrm{NCN})$ on the basis of decision no. DEC-2013/09/N/HS3/02108. 